\title{
LANGKAH MENUJU BUDAYA KESELAMATAN PASIEN DENGAN MELAKUKAN PROMOSI KESEHATAN DAN EVALUASI
}

\author{
Pebi Septrian Sari \\ febi.septrian@gmail.com
}

\section{LATAR BELAKANG}

Keselamatan pasien adalah keadaan pasien bebas dari cedera yang tidak seharusnya terjadi atau bebas dari cedera yang potensial akan terjadi terkait dengan pelayanan kesehatan. keselamatan pasien didefinisikan sebagai freedom from accidental injury. Accidental injurydisebabkan karena error yang meliputi kegagalan suatu perencanaan atau memakai rencana yang salah dalam mencapai tujuan. Accidental injury juga akibat dari melaksanakan tindakan yang salah (commission) atau tidak mengambil tindakan yang seharusnya diambil (omission). Accidendal injurydalam prakteknya akan berupa kejadian yang tidak diinginkan (near miss).

Keselamatan pasien menjadi hak bagi setiap pasien dan harus dilaksanakan demi tercapainya tujuan yakni ketepatan identifikasi pasien, peningkatan komunikasi yang efektif, peningkatan keamanan obat yang perlu diwaspadai, keamanan tindakan bedah, pencegahan risiko infeksi dan pencegahan risiko pasien jatuh. Keselamatan pasien rumah sakit adalah suatu sistem dimana rumah sakit membuat asuhan pasien lebih aman, sistem tersebut meliputi: assessment risiko, identifikasi dan pengelolaan hal yang berhubungan dengan risiko pasien, pelaporan dan analisis insiden, kemampuan belajar dari insiden dan tindak lanjutnya serta implementasi solusi untuk meminimalkan timbulnya risiko. Sistem tersebut diharapkan dapat mencegah terjadinya cedera yang disebabkan oleh kesalahan akibat melaksanakan suatu tindakan atau tidak melakukan tindakan yang seharusnya dilakukan.

Keberhasilan penerapan keselamatan pasien menjadi tanggung jawab seluruh komponen dalam rumah sakit termasuk perawat. Di rumah sakit, salah satu tenaga yang berperan dalam meningkatkan keselamatan pasien adalah perawat. Keselamatan pasien bagi perawat tidak hanya merupakan pedoman tentang apa yang seharusnya dilakukan, namun keselamatan pasien merupakan komitmen yang tertuang dalam kode etik perawat dalam memberikan pelayanan yang aman, sesuai kompetensi, dan berlandaskan kode etik bagi pasien. Sebagai perawat profesional harus berfikir kritis dari setiap tahap karena hal tersebut untuk keberhasilan perawatan terutama dalam tahap evaluasi. Evaluasi bagian dalam mencatat dan 
memperbaiki apa saja yang kurang dari kegiatan promosi kesehatan yang dilakukan bertujuan untuk perbaikan kegiatan promosi kesehatan berikutnya.

Promosi kesehatan mempunyai pengertian dan arti yang sangat relevan. Pengertian promosi kesehatan adalah proses memberdayakan atau memandirikan masyarakat untuk memelihara, meningkatkan dan melindungi kesehatannya melalui peningkatan kesadaran, kemauan dan kemampuan, serta pengembangan lingkungan yang sehat. Promosi kesehatan mencakup aspek perilaku, yaitu upaya untuk memotivasi, mendorong dan membangkitkan kesadaran akan potensi yang dimiliki masyarakat agar mereka mampu memelihara dan meningkatkan kesehatannya. Petunjuk teknis promosi kesehatan di rumah sakit adalah upaya rumah sakit untuk meningkatkan kemampuan pasien, klien, dan kelompok-kelompok masyarakat, agar pasien dapat mandiri dalam mempercepat kesembuhan dan rehabilitasinya, klien dan kelompok-kelompok masyarakat dapat mandiri dalam meningkatkan kesehatan, mencegah masalah kesehatan, dan mengembangkan upaya kesehatan bersumber daya masyarakat, melalui pembelajaran dari, oleh, untuk, dan bersama mereka, sesuai sosial budaya mereka, serta didukung kebijakan publik yang berwawasan kesehatan.

\section{METODE}

Penelitian ini dilakukan dengan menggunakan teknik pengumpulan data yaitu literature review. Dengan melakukan analisis dan kajian bebas pada jurnal, e-book, maupun buku teks yang berkaitan dengan materi pembelajaran yaitu budaya keselamatan pasien dengan memberi promosi kesehatan dan evaluasi kepada pasien yang bertujuan untuk meningkatkan keselamatan pasien, menurunkan risiko pasien jatuh dan membuat pasien lebih mandiri agar mampu mempercepat kesembuhan dan rehabilitasinya.

Bahan kajian yang digunakan pada literature review ini adalah jurnal atau artikel yang didapatkan dari google scholar. Dengan menggunakan 10 sumber referensi jurnal yang diterbitkan pada 10 tahun terakhir. Dalam mencari literature reviewnya, menggunakan kata kunci budaya keselamatan, keselamatan pasien, promosi kesehatan dan evaluasi.

\section{HASIL}

Hasil dari data yang telah dikumpulkan dari berbagai sumber, banyak perawat yang sudah melakukan langkah - langkah keselamatan pasien dengan baik. Tetapi ada beberapa perawat masih kurang tepat dalam melakukan keselamatan pasien yaitu dengan tidak memberikan promosi kesehatan kepada pasien. Promosi kesehatan di dalam rumah sakit 
merupakan bagian penting di suatu lingkungan sikap pola hidup pasien dan keluarga pasien karena mempengaruh keefektifan dari pengobatan yang diberikan oleh rumah sakit. Jika seorang paisen dan keluarga telah mengetahui tentang berbagai penyakit serta cara penyembuhan dan pencegahan penyakit maka hal tersebut akan membantu proses penyembuhan pasien.

\section{PEMBAHASAN}

Penerapan keselamatan pasien yang didukung oleh perawat harus berdasarkan langkah - langkah menuju keselamatan pasien yang menjadi hak bagi setiap pasien di rumah sakit. Sebagaimana dimaksud pada ayat (2) Peraturan Menteri Kesehatan Republik Indonesia Nomor 11 Tahun 2017 Tentang Keselamatan Pasien Rumah Sakit peru disesuaikan dengan perkembangan dan kebutuhan pelayanan difasilitas pelayanan kesehatan. Maka dilakukan pelaksaan tujuh langkah menuju keselamatan pasien agar pelayanan yang diberikan menjadi lebih aman. Tujuh langkah menuju keselamatan pasien meliputi:

1. Membangun kesadaran akan nilai keselamatan pasien

Membangun budaya keselamatan pasien yang terbuka dan adil. Setiap fasilitas pelayanan kesehatan harus mempunyai kebijakan untuk menjabarkan setiap tindakan yang dilakukan seluruh staf pelayanan kesehatan dalam mengurangi risiko dan menangani insiden yang terjadi.

2. Memimpin dan mendukung seluruh staf rumah sakit

Setiap fasilitas pelayanan kesehatan harus memperhatikan kembali struktur dan proses yang ada dalam manajemen risiko klinis dan non klinis, serta memastikan hal tersebut mencakup dan terintegrasi dengan keselamatan pasien.

3. Mengintegrasikan aktivitas dalam pengelolaan risiko

Setap fasilitas pelayanan kesehatan harus memperhatikan kembali struktur dan proses yang ada dalam manajemen risiko klinis dan non klinis, serta memastikan hal tersebut mencakup dan terintegrasi dengan keselamatan pasien.

4. Mengembangkan sistem pelaporan

Perawat dapat menerapkan implementasi dalam melakukan pelaporan kejadian dan insiden yang terjadi secara tepat dan lengkap tanpa dibayangi ketakutan akan hukuman.

5. Melibatkan dan berkomunikasi dengan pasien 
Perawat melakukan komunikasi yang terbuka dalam menjelaskan segala informasi kepada pasien dan keluarga pasien. Pasien dan keluarga pasien harus mendapatkan informasi mengenai rekomendasi untuk perubahan.

6. Belajar dan berbagi pengalaman tentang keselamatan pasien Menganalisis masalah yang telah terjadi untuk mempelajari serta memahami bagaimana dan mengapa insiden itu bisa terjadi. Selanjutnya diskusikan dalam tim tentang pengalaman dari hasil analisis insiden dan penyebab kegagalan medis.

7. Mencegah cedera melalui implementasi sistem keselamatan pasien Gunakan informasi yang tepat, jelas, dan akurat yang dapat diperoleh dari sistem pelaporan, asesmen risiko, kajian insiden, dan analisis untuk menentukan solusi dan mengatasi masalah yang mendasar.

Dengan menerapkan langkah - langkah di atas, promosi kesehatan dapat dilakukan diberbagai tempat di dalam rumah sakit yaitu antara lain dilakukan di ruang rawat inap dengan memberikan promosi kesehatan misalnya mengenai perilaku hidup bersih dan sehat, memberikan penjelasan penggunaan tempat tidur pada pasien dan keluarga pasien demi keselamatan pasien. Di ruang rawat jalan dapat dilakukan promosi kesehatan dengan melakukan penyuluhan kepada individu atau kelompok, kepada pasien dan keluarga yang mengantar. Promosi kesehatan dapat berupa poster, leaflate dan gambar mengenai kesehatan misalnya seperti konseling gizi, KB, konseling kesehatan remaja dan lain - lain sebagai langkah preventif. Di ruang pendaftaran terdapat poster atau spanduk dan isi poster atau spanduk tersebut berisi mengenai alur pelayanan rumah sakit dan berisi informasi kesehatan. Di tempat pembayaran, promosi kesehatan untuk pasien dan keluarga berfokus kepada transaksi pembayaran pelayanan kesehatan dan motivasi serta salam hangat untuk pasien dan keluarga pasien.

Penerapan budaya keselamatan pasien harus dilaporkan oleh perawat baik kejadian kesalahan tidak disengaja dan kondisi yang mengakibatkan atau berpotensi mengakibatkan cedera yang dapat dicegah pada pasien, yang terdiri dari kejadian tidak diharapkan, kejadian nyaris cedera, kejadian tidak cedera dan kejadian potensial cedera. Sejatinya pelaporan insiden keselamatan pasien sangat dibutuhkan oleh semua pihak guna perbaikan pelayanan.

Dalam melakukan keselamatan pasien, maka perlu adanya standar keselamatan pasien sebagai acuan untuk melaksanakan pelayanan kesehatan. Standar keselamatan pasien tersebut 
wajib diterapkan dalam pelayanan kesehatan. Standar keselamatan pasien meliputi 7 standar yaitu :

1. Hak pasien, pasien dan keluarga mempunyai hak untuk mendapat informasi tentang rencana dan hasil pelayanan.

2. Pendidikan bagi pasien dan keluarga, rumah sakit harus mendidik pasien dan keluarganya tentang kewajiban dan tanggung jawab pasien dalam asuhan pasien.

3. Keselamatan pasien dalam kesinambambungan pelayanan, rumah sakit menjamin kesinambungan pelayanan dan menjamin koordinasi antar tenaga dan antar unit pelayanan.

4. Penggunaan metode peningkatan kinerja untuk melakukan evaluasi dan peningkatan keselamatan pasien, rumah sakit harus mendisain proses baru atau memperbaiki proses yang ada, memonitor dan mengevaluasi kinerja melalui pengumpulan data, menganalsis secara intensif KTD, dan melakukan perubahan untuk meningkatkan kinerja serta keselamatan pasien.

5. Peran kepemimpinan dalam meningkatkan keselamatan pasien

6. Pendidikan bagi staf tentang keselamatan pasien

7. Komunikasi sangat penting bagi tenaga kesehatan untuk mencapai keselamatan pasien.

Evaluasi adalah proses penilaian pencapaian tujuan serta pengkajian ulang rencana keperawatan. Evaluasi bertujuan untuk melengkapi proses keperawatan yang menandakan seberapa jauh diagnosa keperawatan, rencana tindakan pelaksanaannya sudah berhasil dicapai. Komponen evaluasi dapat dibagi menjadi 5 komponen yaitu:

1. Menentukan kriteria standar praktik dan pertanyaan evaluatir

2. Mengumpulkan data mengenai status kesehatan klien yang baru terjadi

3. Menganalisis dan membandingkan data terhadap kriteria dan standar

4. Merangkum hasil dan membuat kesimpulan

5. Melaksanakan intervensi yang sesuai berdasarkan kesimpulan

\section{PENUTUP}

Dari penelitian ini dapat disimpulkan bahwa keselamatan pasien adalah hak bagi setiap pasien yang harus diberikan oleh rumah sakit khususnya perawat yang merupakan bagian dari rumah sakit. Upaya yang digunakan di rumah sakit untuk meningkatkan keselamatan pasien 
antara lain melalui program 7 langkah menuju keselamatan pasien di rumah sakit dan penerapan standar keselamatan pasien di rumah sakit.

Dalam proses keperawatan terdapat proses akhir yaitu proses evaluasi. Evaluasi menunjukkan masalah yang telah dipecahkan dan mana yang perlu dikaji ulang, direncanakan kembali, jadi proses keperawatan merupakan siklus yang dinamis berkelanjutan.

\section{DAFTAR PUSTAKA :}

Lombogia, A., Rottie, J., \& Karundeng, M. (2016). Hubungan Perilaku dengan Kemampuan Perawat dalam Melaksanakan Keselamatan Pasien (Patient Safety) di Ruang Akut Instalasi Gawat Darurat RSUP Prof. DR. R. D. Kandou Manado. E-journal Keperawatan. Vol4(2).1-8

Sari, P, N., Yuliana, N,D \& Purwanti,A. (2018). Gambaran Pelaksanaan Promosi Kesehatan Rumah Sakit (PKRS) Di Rumah Sakit Umum Daerah (RSUD) Blambangan Banyuwangi. Jurnal Ilmiah Mahasiswa Kesehatan Masyarakat. Vol.3(4)

Isnaini, N. M., \& Rofii, M. (2014). Pengalaman Perawat Pelaksana dalam Menerapkan Keselamatan Pasien. Jurnal Managemen Keperawatan. Vol.2(1). 30-37

Potter, P., \& Perry, A. G. (2005). Buku Ajar Fundamental Keperawatan: Konsep, Proses dan Praktik. (D. Yulianti, M. Ester, Eds., \& Y. Asih, Trans.) Jakarta.

Depkes RI. (2011). Peraturan Menteri Kesehatan Republik Indonesia. No. 1691 /Menkes/Per/VIII/2011 tentang Keselamatan Pasien Rumah Sakit. Jakarta

Herawati, T, Y. (2015). Budaya Keselamatan Di Ruang Rawat Inap Rumah Sakit X Kabupaten Jember. Jurnal Ikesma. Vol.11(1). 52-60

Prahesti, G,M. (2018). Evaluasi Standar Promosi Kesehatan Di Rumah Sakit Islam Surabaya. Jurnal Promkes. Vol.6(1). 23-34

Harus, B, D (2015). Pengetahuan Perawat TentangKeselamatan Pasien DenganPelaksanaan Prosedur KeselamatanPasien Rumah Sakit (KPRS) DiRumah Sakit Panti Waluya SawahanMalang. Jurnal Care. Vol. 3(1). 25-32 
Riviranty, A. (2015). Analisis Budaya Organisasi dan Budaya Keselamatan Pasien sebagai Langkah Pengembangan Keselamatan Pasien di RSIA Budi Kemuliaan Tahun 2014. Jurnal Administrasi Rumah Sakit Vol.1 No.3 , 196-206.

Nurdianna, F. (2017). Pelaksanaan Promosi Kesehatan Di Rumah Sakit Universitas Airlangga Surabaya. Jurnal Promkes. Vol.5(2). 217-231

Rivai, F.,dkk. (2016). Faktor Yang Berhubungan Dengan Implementasi Keselamatan Pasien Di Rsud Ajjappannge Soppeng Tahun 2015. Jurnal Kebijakan Kesehatan Indonesia. Vol. 5(4). Hal 155-156.

Astuti., Painringi, A, S \& Kadir, R, A. (2018). Pengaruh Elemen People Pada Knowledge Management Terhadap Budaya Keselamatan Pasien Di RSUD A.M Parikesit Tenggarong. JKMM. Vol. 1(2). 178-185

Simamora, R. H., \& Fathi, A. (2019). The Influence Of Training Handover Based SBAR Communication For Improving Patients Safety. Indian journal of public health research \& development, 10(9), 1280-1285. 